\title{
THE TEACHING OF HYGIENE: SOME SUGGESTIONS.*
}

By W. W. STANNTHORPE, M.D., D.P.H., J.P.

Medical Officer of Health for the Guisborough Combined Sanitary District.

Is there one here to-day who in the discharge of his duties as Medical Officer of Health has not at times been discouraged and disheartened by the ignorance, indifference, and fatalism which so often render his recommendations and efforts futile? Ignorance of the laws of nature. indifference to everything but the "gathering of gear," fatalism the result of both. Have we not all felt that these are as difficult to break through as the walls of a prison: ignorance and indifference are walls that must be battered down if we are to succeed in our fight against disease and premature death. How is this to be done?

As Health Officers we must make our voices heard beyond the Councils we serve. We must individually and collectively urge upon Education Committees, school managers, school teachers, the Board of Education itself, the absolute necessity of making personal and domestic hygiene a school subject-compulsory, not voluntary. The present system of education requires radical alteration; it is not education, it is cramming. By-the-way, would not the substitution of the word Eduction for Education impress upon teachers and others the result it is, or ought to be, their object to obtain? But even under the present system there are opportunities for imparting knowledge of the laws governing health which might be utilized. The mid-morning break in the lessons; why not teach the children the why and wherefore of this-the inhaling of fresh air, the exercise of muscles and lungs, the ventilation of the rooms, play as a relief from mental strain?

Some of the schemes I am about to suggest may be considered utopian, nevertheless $I$ am convinced they are desirable.

Schools, except those for infants, should be on the outskirts of towns, in order that the surroundings may be as healthy as possible. The schoolrooms should be, by being models of cleanliness and order, object lessons. To each school or group of schools there should be attached a piece of land where gardening could be taught. Much of hygiene can be so learnt, in fact the lessons are almost innumerablesewage to the soil ; life from life; like produces its like, whether it be good or bad; good crops can only be obtained from the best of

* Read at a meeting of the Northern Branch. 22nd April, 1904. 
seed and soil; weeds must be diligently rooted up; whatsoever a man sows that shall he reap. Gardening itself is a healthy exercise.

In too many schools the physical exercise is simply a farce, a matter of routine performed in a dull and listless way. In fact, so far as the effect is concerned, the time in some instances would be better employed in play. To obtain the best results the interest of the children must be awakened. This, I think, can easily be done. Let the scholars, boys and girls, be formed into companies, each with its officers appointed by the children themselves. Each officer to have the command and superintend the work of a section of a company, of course under the teacher. Esprit de corps and healthy emulation between company and company would result. Militarism, does someone say? Not necessarily so; but even then, this is a lesser evil than an unhealthy race.

During spring and summer, and occasionally at other times, school children should be taken into the country and taught to observe, to cultivate the beautiful, and to study nature. All this promotes the sound mind in the sound body.

The elements of personal and domestic hygiene should be taught in the higher standards. Continuation classes for the teaching of advanced hygiene should be formed. Attendance for a certain number of hours per year until a fixed standard or age has been reached, should be compulsory.

To every school or group of schools there should be connected a house in which girls could be taught the whole round of domestic work, boys so much of it as pertains or would be useful to them. Provision to be made for both boys and girls to live in the house for a certain number of days.

The duties of citizenship, communal duties, should be impressed on the older children. They should be taught to realize that if they partake of the privileges of communal living they must be prepared to forego something of what is generally termed the liberty of the subject. The conscientious objector reaps the benefit of a vaccinated community; he is willing that nurses and doctors and others coming in contact with small-pox patients should undergo what he considers a great risk, but he must have both the privileges of communal living and full liberty of the subject-a law unto himself. The woman who suspects her child to be suffering from a mild attack of, say, scarlet fever, and prefers to remain in ignorance as to the nature of the ailment so that her child may continue to go to school, is not fulfilling her communal duties, and would probably be the first to cry out if her neighbour acted so.

It need hardly be said that in connection with the continuation 
classes on hygiene there should be a system of awards. We have band contests, ambulance competitions, and such like; why not physical drill competitions?

In future the duties of the Medical Officer of Health will have to be more educational or instructive than they are now. In fact, the duties as laid down by the Local Government Board need revision. Much of the Officer's time is taken up by work which can be, and ought to be, carried out by the Inspector of Nuisances. Is there any reason why the Medical Officer of Health should not give lectures in connection with the continuation classes? Should he not also be the examiner?

In conclusion, gentlemen, I trust that the few bald suggestions I have made will lead to a discussion which shall have a practical result.

\section{DISCUSSION.}

Dr. JACKson congratulated Dr. Stainthorpe on the excellence of his paper, and entirely agreed with the sentiments expressed therein.

Dr. Boyd agreed with the tenour of the paper, and considered the teaching of hygiene of the highest importance to future generations, and of the greatest interest to Medical Officers of Health. The question with him was: What is practicable? He was struck with the ignorance displayed by the children taught in Board schools. Other members having spoken.

Dr. Starnthorpe replied. He admitted the difficulty of conveying children to and from schools situated on the outskirts of towns, but considered that where there were trams-a special service for school children should be provided. He considered that the teachers of elementary schools should be recruited from a higher social grade than at present, at least in many instances. As Medical Officers of Health, they ought to be able to go into schools not only for inspection of school buildings, but for a general inspection of the scholars. He considered that the Medical Officers of Health could further the knowledge aimed at by supervising the teaching of hygiene in school continuation classes and as teachers of hygiene to elementary school teachers.

The Paris Municipal Council has voted a grant of $£ 120$ to Professor Grancher in furtherance of his researches as to the means of preventing tuberculosis in schools.

Decrease of Consumption not due to Change of Nomenclature.It has been said of late years that the decrease in the mortality from consumption has been to a certain extent due to reporting these deaths under the head of pneumonia. An investigation was made as to this point in New York with the result of finding very few pneumonia deaths that could properly be attributed to consumption. The investigation is still being continued, and whenever there is reason to believe that a death has been improperly credited, a change is made in the reports. Biggs does not believe that the great and rapid fall of the tuberculosis death rate is a result of false diagnosis. 